\title{
A STUDY ON REAL ESTATE BUSINESS IN SALEM DISTRICT, TAMILNADU
}

\author{
J. SENTHIL VELMURUGAN ${ }^{1} \&$ C. SUGANYA ${ }^{2}$ \\ ${ }^{1}$ Assistant Professor, Periyar Institute Management Studies, Periyar University, Salem, Tamilnadu \\ ${ }^{2}$ Assistant Professor, Department of MBA, Paavai College of Engineering, Namakkal, Tamilnadu
}

\begin{abstract}
Real estate business has emerged as a viral between the middle and upper middle class population in Tamilnadu. Real estate business emerges, because of the high demand among the buyers as it is considered as fixed assets which will give benefits in future. This makes the real estate business a talk of the day. This paper is going to give a wide knowledge about this business and it is going to study about the social economic factors to consider in the real estate business. The researcher collects the data from primary as well as from secondary data. The primary data were collected from structured questionnaire, the secondary data collected from website, referred journal and form articles in the referred books. The researcher used the Percentage Analysis for measuring the social economic factors influencing, the Chi Square Analysis for the reason for choosing the real estate business and ANOVA for the measurement of effectiveness of promotional tools used to realtor. This paper shows that there is a relationship between the social economic factors and the real estate business and the give valuable suggestion for the effectiveness of the promotional tools used in the real estate business.

KEYWORDS: Real Estate \& Promotional Tool
\end{abstract}

Received: Nov 29, 2017; Accepted: Dec 19, 2017; Published: Jan 12, 2018; Paper Id.: IJHRMRFEB20183

\section{INTRODUCTION}

Real Estate Sector is one of the most globally recognized sectors in India. Real Estate is the Second Largest Employer after the agriculture and there is a possibility of $30 \%$ growth in the next decade. The state government has notified the Tamilnadu Real Estate (Regulation and Development) Rules 2017 that prohibited developer from promoting their property in the media without Registration. The latest rule states that promoters should not involve in advertising, book selling and purchase of the plot, apartment or building without registering the real estate project with Tamilnadu Real Estate Regulatory Authority (TNRERA). Mentioning the registration number is mandatory while advertising in the media for the project. This make the researcher to study about the real estate business in Salem District, Tamilnadu and to see their promotional tools effectiveness towards the property.

A survey report on the newspaper shows that there will be a marginal drop in the price after the currency note ban. However, the report had shown a similar fall in the price by 12 months prior to the demonetization.

Knight Frank report shows no change in property price in the past eighteen months (Jan 2016to June 2017) but there is a change of price fall in the future.

Another survey report on the Times of India Shows that Housing demand across top 8 cities during 20162020 estimated at 4.2 million units.

Real Estate consists of four sub sectors 


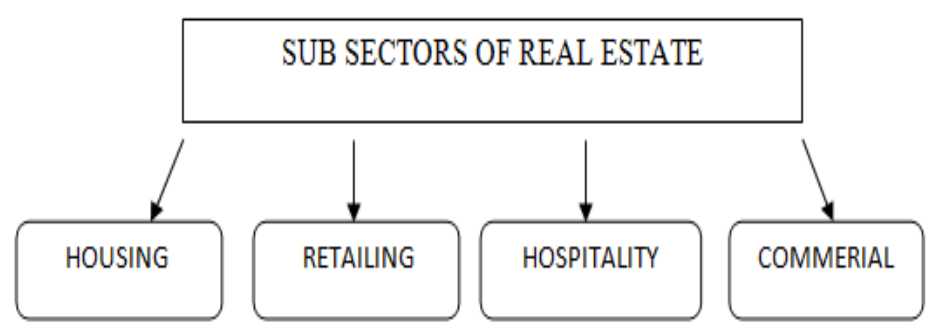

The construction industry is rated third among the 14 major sectors in terms of direct, indirect effect in the all sectors of the economy. The Indian Real Estate Market is expected to touch US\$ 180 billion by 2020. The housing sector alone contributes $56 \%$ of country Gross Domestic Product (GDP). During the period of Financial Year 2008-2020, the market size of this sector is expected to increase at a Compound Annual Growth rate of $11.2 \%$.

Ministry of Housing and Urban Affairs, Government of India under the PradhanMandtriAwarYojana (Urban) sanctioned 2,17,900 new houses to push affordable housing in the urban area of the country.

\section{Objectives}

- To study about the real estate business in Salem district

- To study about the primary reason for choosing the real estate business.

- To study about the promotional tool's effectiveness in Salem district

- To offer suggestions for the further development of business in Salem district

\section{REVIEW OF LITERATURE}

Linqui Wang "Study on customer buying behavior towards the real estate of China vank co Limited., the finding of the study is compared to Radio, TV customer preferred Internet marketing to save time and to have more viewers about the company.

P. Manivannan, Dr. M. Someasundaran, "Purchase of Residential Flats" - Factors Influencing the Decision of Buyer in Selected Cities in Tamilnadu” IRJBM Volume No- VI Sept 2014 - Issue - ( Pg.73). In the Real Estate business the basic amenities is the most important factor which is followed by recreationalleisure, goodwill factors while deciding to purchase the flat.

\section{RESEARCH METHODOLOGY}

Research Methodology is a way of systematically solving the research problem.

\section{Research Design}

The researcher aims to "A Study on Real Estate Business in Salem District Tamilnadu". Convenient random sampling technique is used to collect the data. The study is done under Salem District. The sample size for the study is 75 respondents. The primary data have been collected directly from the realtor by using a questionnaire. The relevant secondary data are collected from different source such as journals, article, newspapers, magazines, internet, periodicals, books, reports, publications of associations related to mobile service providers. The statistical tools used are simple 
percentage analysis, chi-square and ANOVA.

\section{Hypothesis}

H0: To study there is a relationship between education qualifications and the primary reason for choosing the Real Estate Business

H0: To study there is a relationship between age and the promotional tools used in the marketing of the Real Estate business.

H0: To study there is a relationship between involvement in the business and Effectiveness of promotional tools used in the Real Estate Business.

The Percentage Analysis is used to measure the Socio - Economic factor, the Chi-square is used to measure the relationship between the education qualification and the primary reason for choosing the Real Estate Business as well as to measure the relationship between the involvement in the business and Effectiveness of Promotional tools used in the Real Estate Business. ANOVA is used to measure the relationship between the age and the promotional tools used in the marketing of the real estate business.

\section{DATA ANALYSIS AND INTERPRETATION}

Table 1: Age of the Respondent
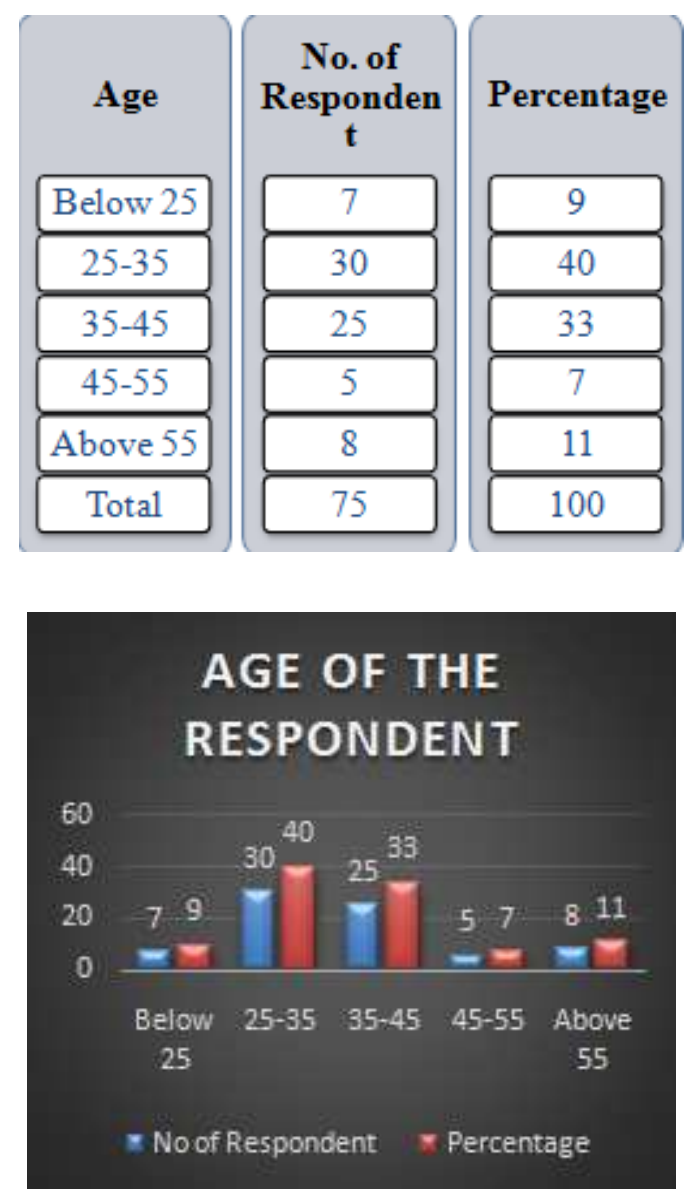

Figure 1: Age of the Respondent 
Table 2: Gender of the Respondent
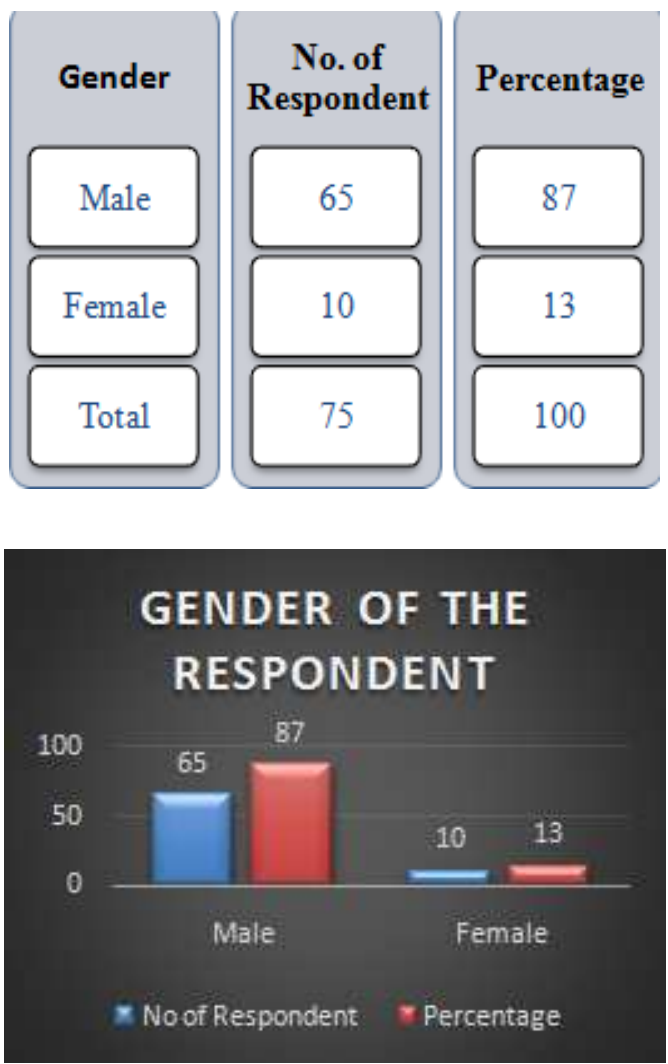

Figure 2: Gender of the Respondent

Table 3: Education Qualifications

\begin{tabular}{|c|c|c|}
\hline $\begin{array}{l}\text { Educational } \\
\text { Qualification }\end{array}$ & $\begin{array}{c}\text { No. of } \\
\text { Respondent }\end{array}$ & Percentage \\
\hline Plus 2 & 10 & 13 \\
\hline Diploma & 35 & 47 \\
\hline Degree & 16 & 21 \\
\hline PG & 14 & 19 \\
\hline Total & 75 & 100 \\
\hline
\end{tabular}

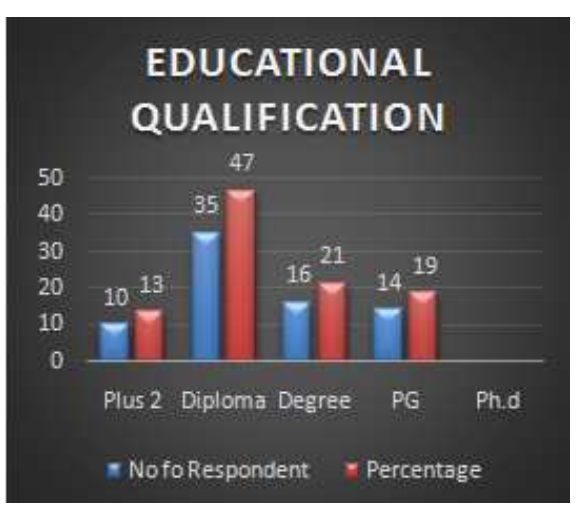

Figure 3: Education Qualifications 
Table 4: Experience of the Respondent

\begin{tabular}{|c|c|c|}
\hline Experience & $\begin{array}{c}\text { No. of } \\
\text { Respondent }\end{array}$ & Percentage \\
\hline $\begin{array}{c}\text { Below } 1 \\
\text { year }\end{array}$ & 12 & 16 \\
\hline $1-5$ year & 19 & 25 \\
\hline 5-10 year & 23 & 31 \\
\hline $10-15$ year & 15 & 8 \\
\hline Total & 75 & 100 \\
\hline
\end{tabular}

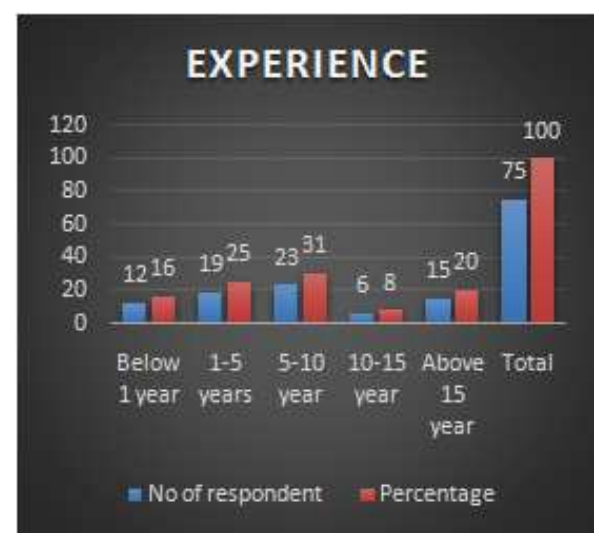

Figure 4: Experience of the Respondent

Table 5: Nature of the Business
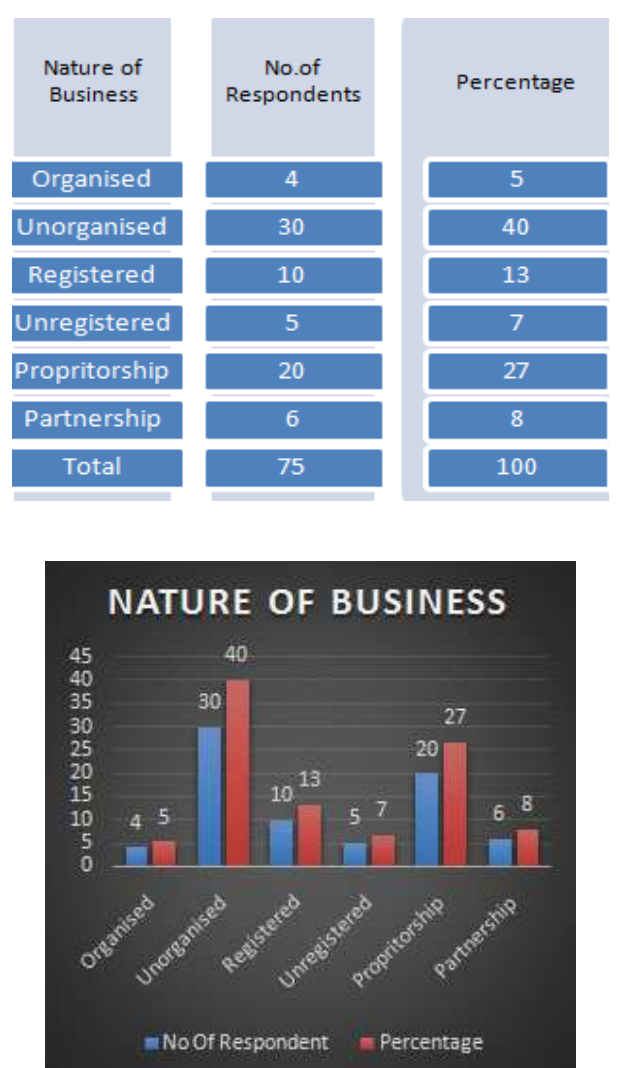

Figure 5: Nature of the Business 
Table 6: Involvement in Business
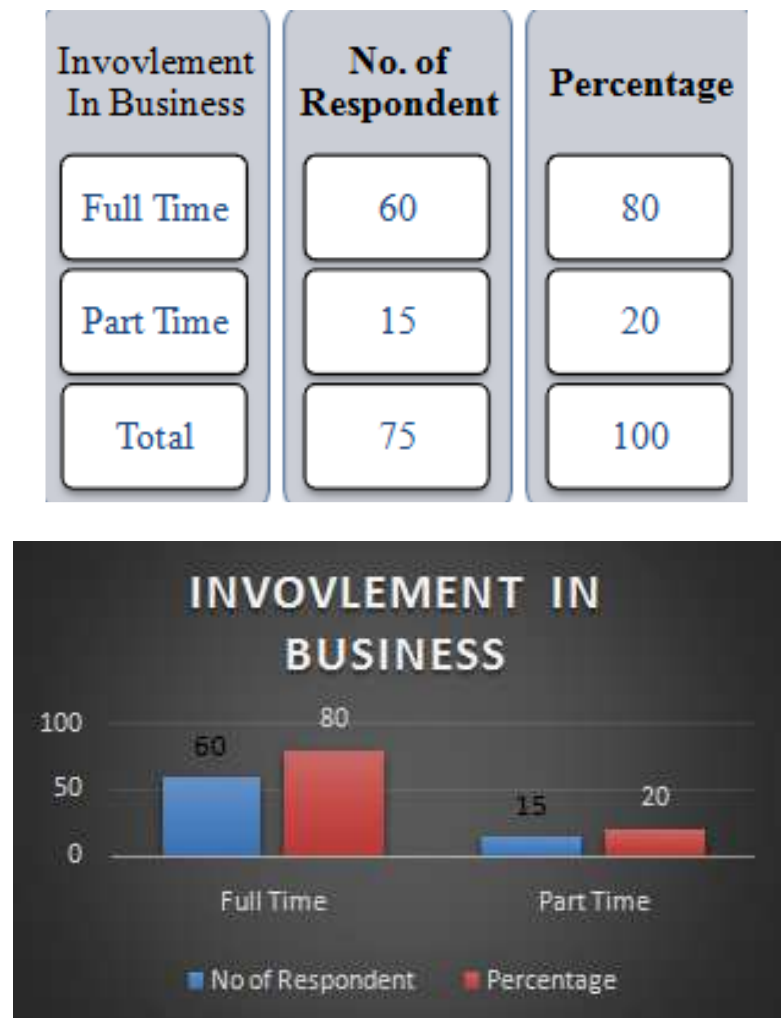

Figure 6: Involvement in Business

Table 7: Primary Reason for Choosing REB

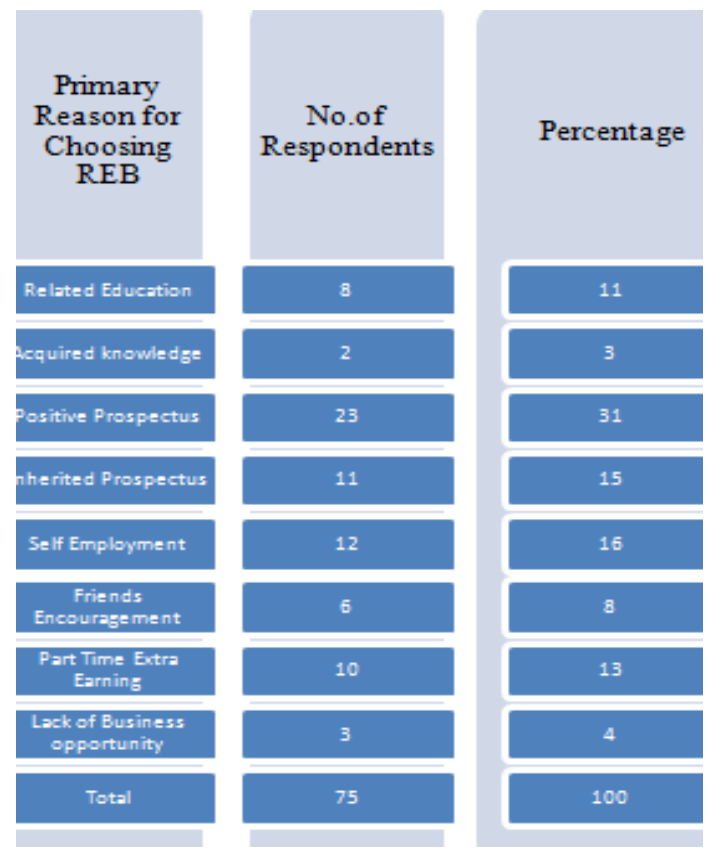




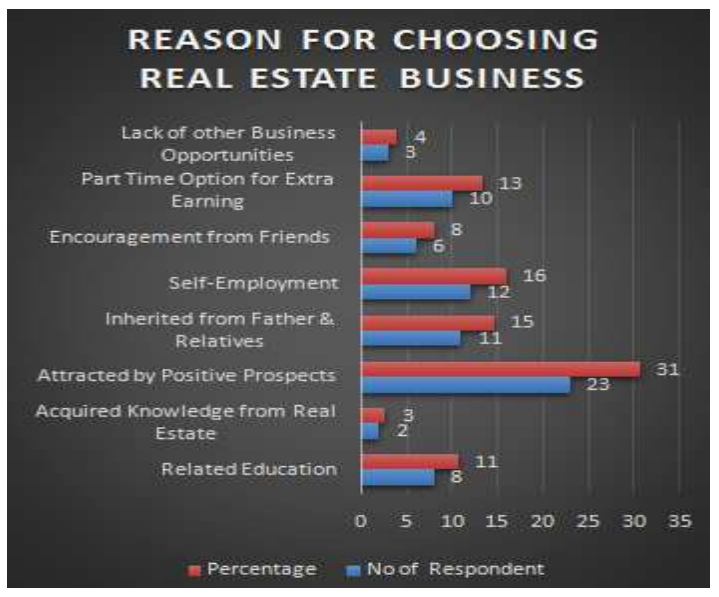

Figure 7: Primary Reason for Choosing REB

Table 8: Category of Real Estate Business
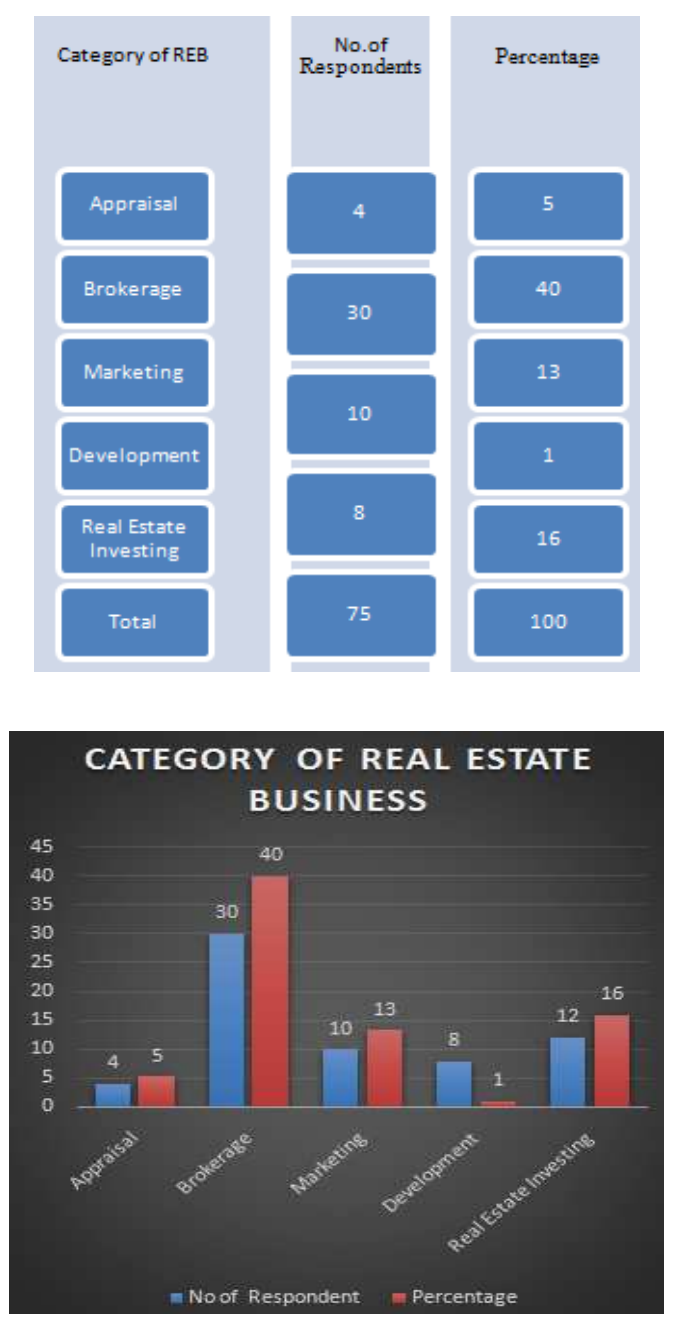

Figure 8: Category of Real Estate Business 
Table 9: Promotional Tools Used in REB
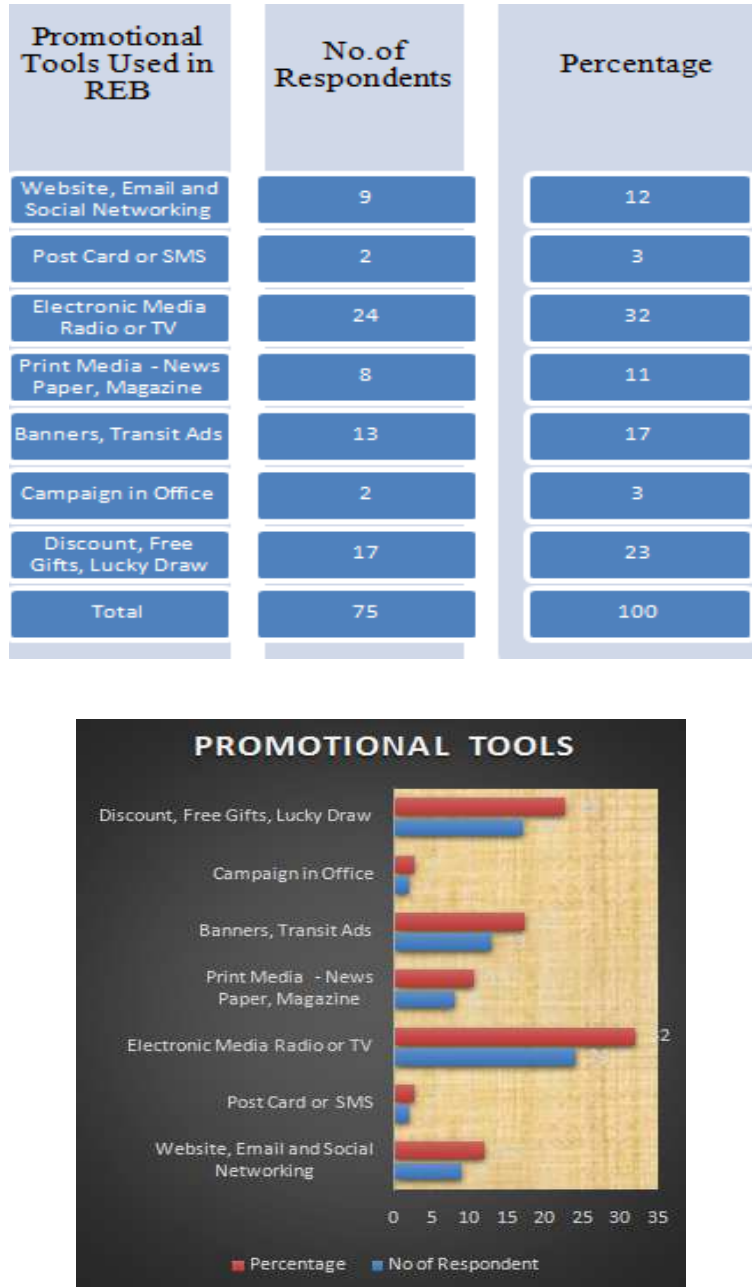

Figure 9: Promotional Tools Used in REB

Table 10: Effectiveness of Promotional Tools

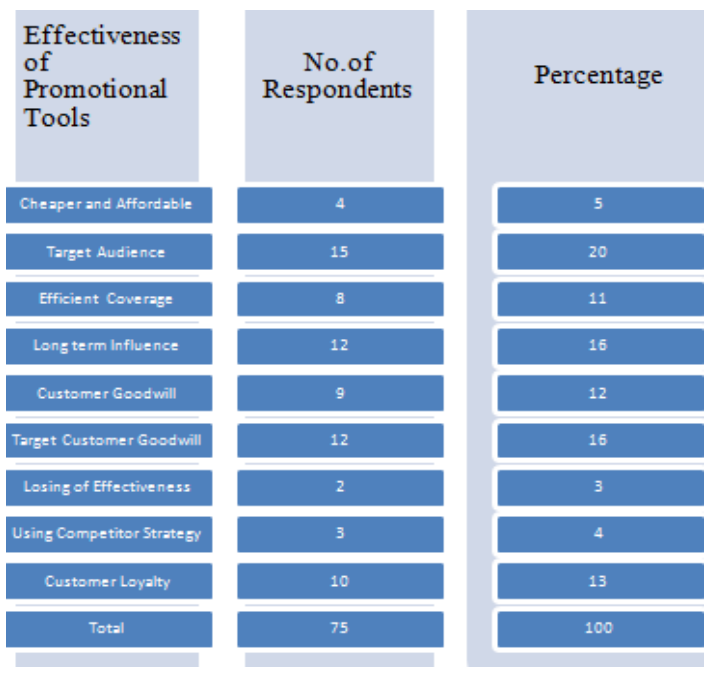




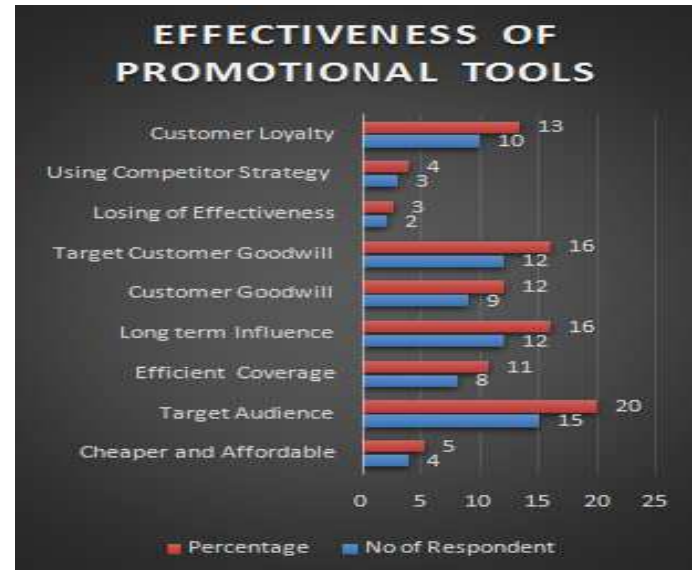

Figure 10: Effectiveness of Promotional Tools

Table 11: Source of Funds
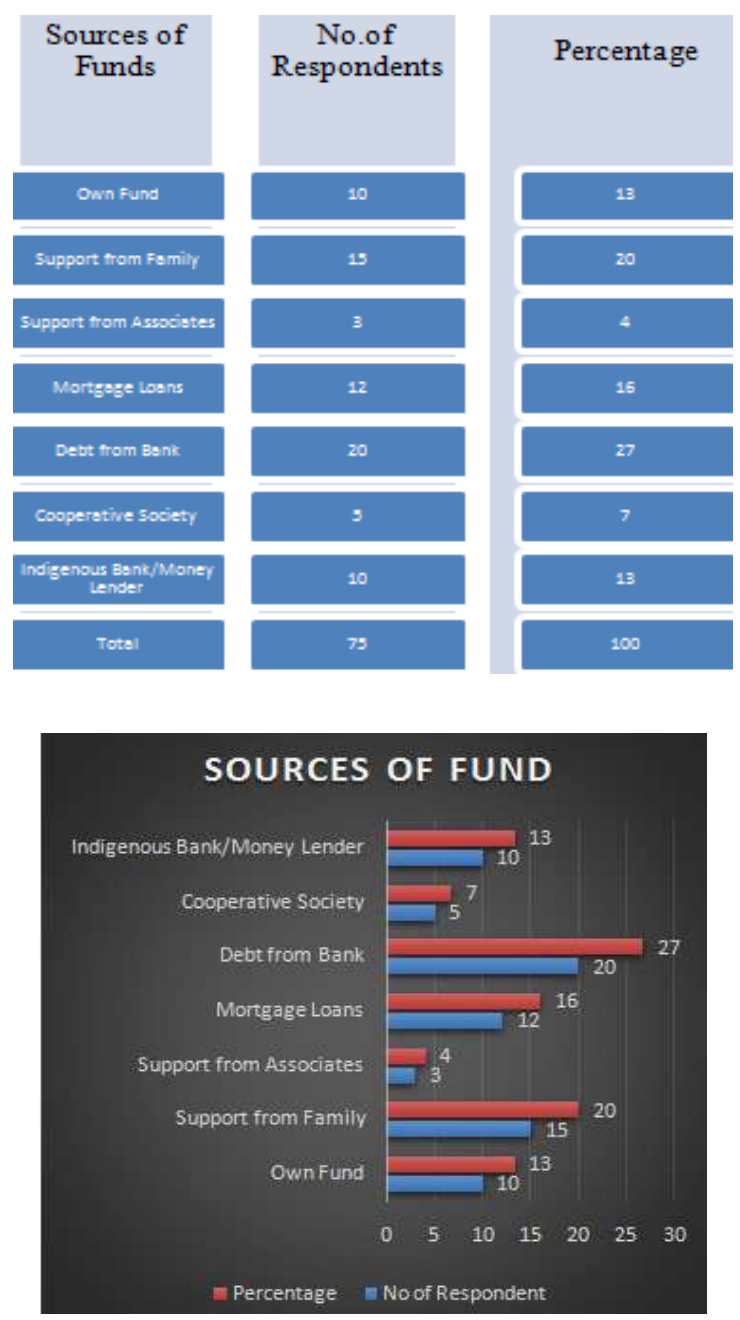

Figure 11: Source of Funds 


\section{Chi Square Analysis I}

\section{Relationship between Educational Qualification of Respondents and Primary Reason for} Choosing he Real Estate Business

\section{HYPOTHESIS}

H0: To study there is no relationship between education qualifications and the primary reason for choosing the Real Estate Business

H1: To study there is a relationship between education qualification and the primary reason for choosing the Real Estate Business

\begin{tabular}{|l|c|c|c|}
\hline \multicolumn{4}{|c|}{ Chi-Square Tests } \\
\hline & Value & df & Asymp. Sig. (2-sided) \\
\hline Pearson Chi-Square & $1.393 \mathrm{E}^{\mathrm{a}}$ & 21 & .000 \\
\hline Likelihood Ratio & 124.226 & 21 & .000 \\
\hline Linear-by-Linear Association & 14.739 & 1 & .000 \\
\hline N of Valid Cases & 75 & & \\
\hline
\end{tabular}

\section{INFERENCE}

Since calculated value is less than the tabulated value (.000.> 0.05), we, accept the null hypothesis (H0), and reject alternate hypothesis (H1).

There is no relationship between educational qualification of respondents and primary reason for choosing the Real Estate business

\section{Chi Square Analysis 2}

\section{Relationship between Involvement in Respondents and Promotional Tools Used in the Real Estate Business} HYPOTHESIS

H0: To study there is no relationship between Involvement in Respondent and the Promotional tools used in the Real Estate Business

H1: To study there is relationship between Involvement in Respondent and the Promotional tools used in the Real Estate Business

\begin{tabular}{|l|c|c|c|}
\hline \multicolumn{4}{|c|}{ Chi-Square Tests } \\
\hline & Value & df & Asymp. Sig. (2-sided) \\
\hline Pearson Chi-Square & $5.556^{\mathrm{a}}$ & 8 & .697 \\
\hline Likelihood Ratio & 7.418 & 8 & .492 \\
\hline Linear-by-Linear Association & .207 & 1 & .649 \\
\hline N of Valid Cases & 75 & & \\
\hline
\end{tabular}

12 cells $(66.7 \%)$ have expected count less than 5 . The minimum expected count is. 40 .

\section{INFERENCE}

Since calculated value is greater than the tabulated value $(0.697<0.05)$, we, reject the null hypothesis $(\mathrm{H} 0)$, and accept the alternate hypothesis (H1).

There is relationship between Involvement in the Business and the Effectiveness of Promotional Tools used in the Real Estate business 


\section{ANOVA}

\section{VARIATION ONAGE THE RESPONDENT REGARDING THE PROMTOTIONAL} TOOLS USED IN THE REAL ESTATE BUSINESS.

\section{AIM}

To find out the difference between age of the respondent and the promotional tools used in the Real Estate Business.

Ho: There is no variation on age of the respondent regarding the promotional tools used in the Real Estate Business

H1: There is variation on age of the respondent regarding the promotional tools used in the Real Estate Business

\begin{tabular}{|l|c|c|c|c|c|}
\hline \multicolumn{1}{|c|}{ Age } & $\begin{array}{c}\text { Sum of } \\
\text { Squares }\end{array}$ & df & Mean Square & F & Sig. \\
\hline Between Groups & 67.541 & 6 & 11.257 & 37.511 & .000 \\
\hline Within Groups & 20.406 & 68 & .300 & & \\
\hline Total & 87.947 & 74 & & & \\
\hline
\end{tabular}

\section{INFERENCE}

It could be inferred from the above table that $\mathrm{F}$ ratio is not significant (0.00). Hence we accept the null hypothesis and reject the alternate hypothesis.

It could be concluded that there is no variation on the age of the respondents about the promotional tools used in the Real Estate business in Salem District.

\section{Findings}

From this study, the researcher found that the majority of the respondents belongs to the age group of $25-35$ years, and male. The primary reason for choosing this Real Estate Business are attracted by the positive prospects in this business, self-employment purpose and few are the inherited from father and relatives. The majority of the category of real estate business is done for the brokerage amount and for good investment in the future. The promotional tools used by the respondents are electronic media like radio or TV, discount, offers and banners and networking. The reason for the effectiveness of promotional tools for the target audience, long term influence in this business and to satisfy the target audience. By Chi-Square analysis, it shows that there is no relationship between the education and the primary reason for choosing the Real Estate Business and there is a relationship between the Involvement in the Real Estate Business and Effectiveness of the Promotional tools used in the Real Estate.

\section{Suggestion}

This research is about the study of real estate business in Salem District, Tamilnadu, most of the nature of real estate business are done in unorganized manner, which means those who are having good knowledge in this business started doing for the positive prospects and focusing on the high brokerage amount from the seller part. When it is unorganized there is a possibility of tax waiving. The promotional tools used by the respondent are electronic media like giving advertisement in the local channels and Radios, they are weak in focusing on the lucky draw, free gifts and discount for the first come first deserve. The effectiveness of the promotional tools is depending upon the business like wise in this 
real estate business they focus on target audience for their earning of goodwill as well as to maintain the loyalty but in this main thing they failed in focusing efficiency and the strategy followed by the competitor to cover the target audience. The main reason for the real estate business failed due to borrowing of the fund of bank and mortgage loans the interest rate is high compared to the other sources.

\section{CONCLUSIONS}

To conclude, the result of the study reveals that the real estate business in Salem district, Tamilnadu, the most important factor affecting them in growth if fail to focus on the promotional tool, and its effectiveness.

The study also reveals that there is no significant difference between education and primary reason for choosing the real estate business and also there is no variation between the age of the respondent and the promotional tools used in the Real Estate Business. The Chi Square analysis resulted that there is a relationship between the involvement in the business and the Effectiveness of Promotional Tools used in the Real Estate Business

This study will be further used to analysis the growth and opportunity for this business in Salem District, Tamilnadu

\section{REFERENCES}

1. SatyanarayananIyyer "Real Estate price dipped after DeMon? Nov 16,2017 in Times of India News Paper

2. YogeshKadirdoss "Circular that gave rise to Real Estate Malpractices withdrawn" Nov 14, 2017 in Times of India News Paper.

3. Sobia Khan "Housing Demand across Top 8 Cities during 2016-2020 estimated at 4.2 million units - India Times Newspaper

4. Restriction to Advertise Real Estate without the Registration Number August 10, 2017 in Times of India paper.

5. Meena Kumari, Private Equity in Real Estate Trends, Progress and Challenges, International Journal of Economics, Commerce and Research (IJECR), Volume 5, Issue 4, July - August 2015, pp. 1-8

6. Wang, S., Yang, Z., \& Liu, H. 2011. Impact of urban economic openness on real estate prices: Evidence from thirty-five cities in China. China Economic Review, 22(1), 42-54. 